\title{
Recidiva de carcinoma de células con trombo en cava a nivel de incisión
}

\section{Clear cells carcinoma relapse in surgical incision}
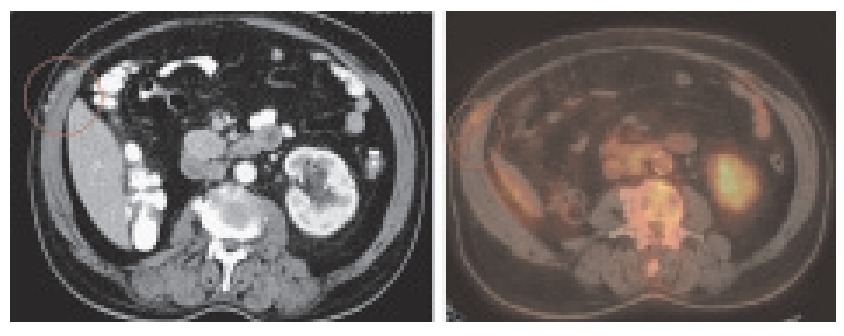

Figuras 1 y 2 - Paciente de 60 años diagnosticado de tumor renal derecho con trombo en cava intervenido mediante nefrectomía ampliada y extirpación de la trombosis con circulación extracorpórea. Un año y 3 meses después en el TAC de control llama la atención la presencia de implantes tumorales subcutáneos situados en el músculo oblicuo externo derecho (figura 1) con captación en el PET (figura 2).
Javier Barba Abad ${ }^{a, *}$, Egoitz Tolosa Eizaguirre ${ }^{a}$, Anibal Rincón Mayans ${ }^{a}$, Luís Romero Vargas ${ }^{a}$, Isabel Vivas Pérez ${ }^{\mathrm{b}}$ y Jose María Berián Polo ${ }^{\mathrm{a}}$

aDepartamento de Urología, Clínica Universidad de Navarra, Navarra, España

bervicio de Radiodiágnostico, Clínica Universidad de Navarra, Navarra, España

*Autor para correspondencia.

Correo electrónico: javiferbar@hotmail.com (J. Barba Abad) doi: 10.1016/j.acuro.2010.02.052

\section{Huevo duro: tumor de testículo quemándose}

\section{Hard-boiled egg: a testicle tumor with burning sensation}

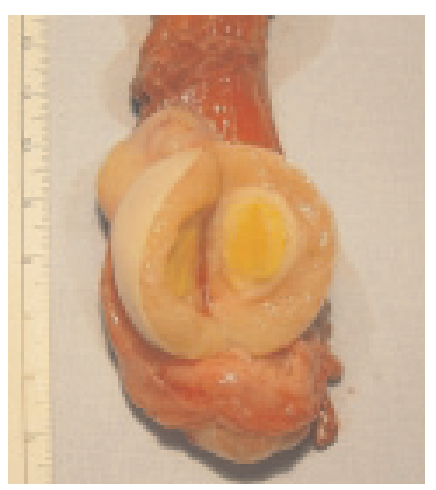

Figura 1 - Pieza de orquiectomía radical izquierda con tumor testicular constituido por un nódulo amarillento que microscópicamente corresponde a un área isquémiconecrótica y con restos neoplásicos concordantes con tumor germinal del tipo seminoma (proceso evolutivo de tumor testicular «quemado» o «burn out»).
Angel Maximino Castro-Iglesias ${ }^{\mathrm{a}, *}$, Antonio Pazos-Riveiro ${ }^{\mathrm{b}} \mathrm{y}$ Antonio Selas-Perez ${ }^{\mathrm{C}}$

\footnotetext{
${ }^{a}$ Servicio de Urología, Hospital Xeral de Vigo, Galicia, España ${ }^{\mathrm{b}}$ Servicio de Urología, Hospital Miguel Domínguez de Pontevedra, Galicia, España

'Servicio de Urología, Hospital Montecelo de Pontevedra, Galicia, España

*Autor para correspondencia.

Correo electrónico: amaxicas@hotmail.com (A.M. Castro-Iglesias) doi: 10.1016/j.acuro.2010.02.053
} 